\title{
AUTOCRATIZATION AS AN IDEOLOGICAL PROJECT
}

\section{Carl Schmitt's anti-liberalism in South Asia}

\author{
David G. Lewis
}

This volume provides evidence of a clear trend of autocratization in South Asian politics, which forms one strand of a much broader global process of 'democratic recession' since 2006 (Diamond 2021). In this chapter I argue that this process should not only be interpreted as a decline in the effectiveness of democratic institutions, as suggested by terms such as 'democratic backsliding' (Bermeo 2015). Autocratization should also be understood as the construction of a new form of governance, a political system that reasserts hierarchy and authority at the centre of political life while claiming to reflect the will of the people. In this chapter I use the work of the anti-liberal political theorist Carl Schmitt to demonstrate a theoretical coherence to this illiberal model of political governance that helps us to think comparatively about the ideational framework of autocratization, not only across South Asia, but on a global scale.

Attempts to explain the new wave of authoritarianism in Asia have largely overlooked the role of ideas and political theory. Croissant and Haynes (2021), for example, identify seven factors driving 'democratic regression' in Asia, but focus primarily on institutional weaknesses, such as the role of political parties and civil society and the extent to which power is concentrated in a presidency. Ding and Slater (2021) also explore the institutional aspects of autocratization, pointing to the structural tensions between electoral and rights institutions in democracy. Diamond highlights the agency of 'elected political leaders, greedy for power and wealth, who knock away various types of constraints on their power and enlarge and entrench it in undemocratic ways' (Diamond 2021: 30). Their success - or otherwise - is down to the resilience - or otherwise - of political institutions such as parties, civil society, and the judiciary.

These explanations tend to overlook ideational and normative aspects of autocratization, including those embedded in processes of globalisation. When the political impact of globalisation is discussed, scholars of comparative authoritarianism tend to focus on the disruptive effects of economic globalisation on communities. But it is also worth emphasising that liberal norms and liberal ideas - both those deliberately promoted by governments and non-governmental organisations (NGOs) and norms spread by contemporary culture, global travel and education - also provoke resistance and revanche in many communities. When authoritarian leaders weigh in against 'liberal elites' and their cosmopolitan ideas, this is not simply a populist device to mobilise populist support, but an ideological campaign informed by illiberal ideas. This 'global illiberalism' takes on country-specific forms, but has common roots in its rejection 
of many aspects of post-Cold War international liberalism - a set of ideas that emphasised a pluralism of actors, the deconstruction of authority, a spaceless internationalism, and fluid and contingent identities (Bettiza and Lewis 2020). In opposition to liberal norms, autocratization in South Asia has been informed by a set of illiberal ideas, reasserting notions of authority, reifying boundaries of the political community, and seeking a new fixity of identity, defined by essentialised understandings of gender, sex, race, religion, and nation.

\section{Carl Schmitt as a theoretician of autocratization}

To explain the ideological framework of contemporary autocratization, I turn to the work of Carl Schmitt. Described as the 'twentieth century's foremost critic of liberalism' (McCormick 1998: 830), Schmitt achieved notoriety through his support for the Third Reich, his advocacy of Nazi expansionism, and his virulent anti-Semitism (Mehring 2014). Schmitt was a jurist by training; his work is at heart a foundational critique of liberalism and an argument in favour of authoritarian forms of political order as both more sustainable and - in Schmitt's particular understanding - as more democratic than the liberal, parliamentary state. Despite his reprehensible personal biography, Schmitt's critiques of liberalism and US foreign policy have inspired followers both among radical right-wing movements and on the European left (Müller 2003). In recent years his work has spread to other parts of the world, particularly Russia (Lewis 2020a) and China (Zheng 2015; Libin and Patapan 2020), where his anti-liberal thought has been hugely influential. In South Asia Schmitt's reach remains more limited, but his political theory has been deployed recently in discussions of the politics of Hindutva in India (Basu 2020) and the conflict in Sri Lanka (Lewis 2020b). Here I explore four of Schmitt's ideas that help us to interpret autocratization's third wave and to develop a comparative theoretical framework to identify and interpret many common and overlapping trends across very distinct political contexts.

\section{Sovereign power}

Schmitt's understanding of politics was informed by his experience of the Weimar republic, which he viewed as a weak polity fatally undermined by pluralist politics and liberal ideas. His response was a radical rejection of political pluralism and an assertion that political order is only possible when all decision-making power is concentrated in a fully sovereign political leader. Schmitt defines sovereignty not as 'the monopoly to coerce or to rule, but as the monopoly to decide' (Schmitt 1985a: 13). The true sovereign is an unconstrained political leader, who can take any necessary decisions to respond to existential threats to the state, without needing to consult parliament, follow laws or comply with constitutional constraints. The sovereign is defined by Schmitt as 'he who decides on the exception' (Schmitt 1985a: 5); the sovereign power is the leader who can declare an exceptional situation in which normal laws and rules do not apply and take any necessary decisions to address the emergency. In Schmitt's world, sovereigns are not despots - they do not act on a whim or take arbitrary decisions, nor do they monopolise decision-making on everyday issues, where norms and rules still apply. But in the extraordinary case, the sovereign can make any necessary decisions unconstrained by law or constitution.

The Schmittian sovereign is an ideal type, but the personalised dictatorship is a global trend, with the percentage of authoritarian states defined as personalist almost doubling to $40 \%$ between 1988 and 2017 (Kendall-Taylor, Frantz, and Wright 2017: 8). South Asia is no exception to this trend. In Sri Lanka President Gotabaya Rajapaksa has continued the drive of the wartime regime run by his brother and former president, Mahinda, to subordinate parliament 
and the judiciary to the regime's will and perpetuate strongman politics (Lewis 2020b; Mihlar, Chapter 25 of this volume). In Bangladesh, what was once a contested political system, in which political power was fought over by two major parties, has deteriorated into a de facto one party system, dominated since 2009 by the personalised political leadership of Awami League leader Prime Minister Sheikh Hasina (Riaz 2020; Ruud, Chapter 22 of this volume). As Riaz comments, 'The demands for her intervention in solving any problems, from capital market $[\ldots]$ to school-level examinations, only reaffirms that there is no other power center in the country' (Riaz: Chapter 18 of this volume). In India Narendra Modi has sought a similar monopoly of decision-making powers in the office of the Prime Minister, achieved through the marginalisation of other government agencies and ministries, parliament and the courts. Critics argue that the government pushes laws through parliament without proper scrutiny. After a controversial ten-day parliamentary session in September 2020, in which the government rushed through controversial new laws, Pratap Bhanu Mehta wrote that the parliament is moving 'from being the custodian of the dignity of legislation to being a site for the acclamation of authoritarianism' (Mehta P. B. 2020).

Schmitt's sovereign is defined by his or her ability to declare the exception, to define a particular situation as one in which the normal rules no longer apply. But there are no preconceived criteria to determine when this state of exception might be invoked: it is the sovereign who decides when there is an emergency and how to respond to it. A culture of exceptionalism has long been a familiar feature of South Asian politics, particularly in securitised environments and counter-insurgency campaigns. But the exception - declared in response to an emergency situation or an existential threat to the state - too easily becomes the norm, an everyday mechanism of governance, not a limited and time-bound aberration from the rules. In Sri Lanka emergency rule introduced temporarily in 1958 has continued in force for much of its modern history. Together with the provisions of the Prevention of Terrorism Act (PTA), these emergency regulations severely limit civil rights in sharp contradiction to international standards (Coomaraswamy and de Los Reyes 2004). In India the Armed Forces (Special Powers) Act (AFSPA) - also introduced in 1958 in the North-East - gives the government the right to declare that a particular area is 'disturbed' (in Schmittian terms, to declare it 'exceptional'). The declaration is not subject to judicial review, but the act effectively gives impunity to security forces to act as they see fit (HRW 2020).

But the Schmittian sovereign is not bound even by the very limited constraints of emergency regulations. The culture of exceptionalism extends even outside these limited legal frameworks. In Sri Lanka there is a long history of extrajudicial killings and disappearances, which was revived during the presidency of Mahinda Rajapaksa (DeVotta 2011). A series of notorious 'White Van' disappearances punctuated the war against the LTTE in 2006-2009 (Lewis 2020b). In Bangladesh, according to human rights defenders, between 2009 and 2018 at least 1,921 people became victims of extrajudicial killings and 109 were victims of enforced disappearances (Riaz, Chapter 18 of this volume). Indian policing demonstrates how easily the exception becomes the norm: critics argue that in everyday policing in India, poorer and marginalised social groups face police and security forces that suffer from an 'infamous record of systematic brutality, disappearances, systemic corruption and a chronic lack of investigative capacity' (Hansen 2019: 24). Extrajudicial killings have been commonplace historically, particularly in areas of conflict such as Assam and Kashmir. Police 'encounter' killings remain frequent against alleged criminals. In India's most populous state, Uttar Pradesh, police killed at least 119 suspects in such incidents in 2017-2020 (Mehta T. 2020). These extrajudicial killings are often celebrated by the public, rather than condemned, confirming Schmitt's instinct that the popular will always prefers a sovereign decision on justice rather than endless, liberal procedural 
wrangling in a flawed and corrupted court system. Schmittian decisionism becomes alluring to the populace when the alternative is a radical dispersal of power and authority in such a way that institutions become ineffectual.

\section{Rule of law}

An obvious corollary of the idea of sovereign power is that it excludes the possibility of the supremacy of law. Schmitt's understanding of law is diametrically opposed to the liberal concept of a rule of law, in which the judiciary stands aside and above the political fray. 'All law', argues Schmitt, 'is situational law': the law must be rooted in the concrete order, the cultural and political realities of the time, and not rely on universal norms promoted without regard to the political context. Schmitt rejects the idea of a positivist legality based on 'free-floating' norms: instead, '[1]ike every other order, the legal order rests on a decision and not on a norm' (Schmitt 1985a: 10). Schmitt opposes any idea that courts could be decision-making subjects in political affairs - for example, through processes of judicial review - because that line of reasoning produces an 'ersatz sovereign' which destabilises the political order (Meierhenrich and Simons 2016: 30). Schmitt contrasts what he views as the weak liberal idea of legality with political legitimacy. The danger, according to Schmitt, is that legality undermines the legitimacy of a sovereign leader, which is derived from the 'people's plebiscitarian will' (Schmitt 2004: 9). Ultimately, it is not for the judiciary to resolve or decide major political questions these are the preserve of the sovereign. A normal, functioning judiciary must exist, but it cannot act as a counterbalance or constraint on sovereign power.

This assertion of political legitimacy over legality echoes across contemporary South Asian politics, where political leaders have often worked to undermine an already fragile independence of the judiciary. In Sri Lanka the impeachment of the Chief Justice Shirani Bandaranayake in 2013 was an important indicator of an illiberal turn in Sri Lankan democracy and interpreted at the time as 'the latest step in the gradual but systematic dismantling of the rule of law' (Crisis Group 2013). In Bangladesh in 2017 the Chief Justice of the Supreme Court retired and left the country, but he later claimed that he had been forced out after several rulings he had made against the government. The Awami League launched a campaign of politically motivated prosecutions against opposition leader Khaleda Zia and many of her associates: in 2018 she was sentenced to 17 years in prison. In India, human rights defenders accused the government of using the law for political ends. Human Rights Watch claimed that the government 'increasingly harassed, arrested, and prosecuted rights defenders, activists, journalists, students, academics, and others critical of the government or its policies' (HRW 2021). The government's critics claimed that the Indian Supreme Court no longer acted as an effective check on executive power. A.P. Shah, a former chief justice of the Delhi high court, warned of the decline of the Supreme Court as part of 'a larger, deliberately-crafted strategy on the part of the executive to seize control of the arms of the state, in ways that would benefit its own political agenda' (Shah 2020). This pattern of assaults on the rule of law across the region reflects the ascendancy of a generation of political leaders who view the judiciary not as an important mechanism of constraint on the executive, but as an obstacle to sovereign decision-making and a potential instrument of political power against their opponents.

\section{Friend/Enemy}

Schmitt makes a critical distinction between 'politics' - the everyday competition among parties and political leaders, which Schmitt treats with disdain - and 'the political', the foundational 
distinction between 'friend' and 'enemy' that in Schmitt's view defines the political community. In Schmitt's well-known aphorism: 'The specific political distinction to which political actions and motives can be reduced is that between friend and enemy' (Schmitt 2007a: 26). This apparently simple idea has far-reaching consequences. It defines the political community not on the basis of citizenship, or even ethnicity or nationality, but on something more elusive - a collective decision to define the enemy. This constructs an external boundary to the community that marks a constitutive dividing line between friend and enemy.

But the politics of enmity not only defines an external boundary to the community. It also effectively delegitimises pluralism within the community. Schmitt firmly rejects any suggestion that "within one and the same political entity, instead of the decisive friend-and-enemy grouping, a pluralism could take its place without destroying the entity and the political itself' (Schmitt 2007: 45). The people must be united in their identification of the enemy, but it is inevitable that the search for an external enemy also identifies internal enemies. Schmitt's own bitter personal biography, haunted by his role in the rise of anti-Semitism in Nazi Germany, should be sufficient warning about the potential consequences of a politics defined by the friend/enemy distinction. The 'political enemy' is 'the other, the stranger; $[\ldots]$ he is, in a specially intense way, existentially something different and alien, so that in the extreme case conflicts with him are possible' (Schmitt 2007: 27). But this leaves the identity of the enemy open to multiple interpretations and leaves the definition of the boundary line of the community (them/us) as open to contestation. The enemy can be anybody - a religious or sexual minority, a political party, a religious sect, a group of migrants or foreigners. It is the enmity line itself - not the identity of the enemy - that becomes politically relevant.

Across South Asia, attempts to forge identity through the identification of the enemy are not new. Indeed, many patterns in the modern politics of South Asia can be traced to an original, foundational division - the 1947 Partition between India and Pakistan. That dividing line continues to shape regional geopolitics and political identity in both countries. Nevertheless, across the region a process of contemporary autocratization has also been accompanied by an intensifying trend towards the construction of political communities through difference - the constant drawing of dividing lines between friend and enemy, between Sinhala and Tamil, Buddhist and Muslim, Hindu and Muslim, Indian and Pakistani. These historical cleavages have been compounded further by new divisions in society, evident in the campaigns against Pakistan's 'Aurat Azadi March' (Women's Freedom March), for example, or Islamist views of atheists and urban women in Bangladesh, which to varying degrees have been accommodated by national governments. The intensity of these campaigns to define enemies and to draw boundaries within and around communities surely reflects much wider anxieties about identity in an era of global change, in communities disrupted by mobility, economic upheavals and powerful new social trends. Schmitt understood only too well how defining the enemy could act as a powerful driver of identity formation. In his own phrase: 'Tell me who your enemy is and I will tell you who you are' (Schmitt 1991: 243).

The friend/enemy distinction is primarily invoked through discourse, but in India critics of the BJP government view new legislation as contributing to this divisive agenda. The 2019 Citizenship (Amendment) Act in India appears to be just such a boundary-producing mechanism, accelerating citizenship - membership of the political community - for non-Muslim immigrants from neighbouring states. Critics claim that the planned creation of a National Population Register (NPR) risks stripping citizenship from Muslims who do not have the required documentation (Basu, Chapter 3 of this volume). These legislative innovations were preceded by a sharp rise in sectarian violence, in which pro-BJP vigilante groups were given considerable leeway to threaten and attack Muslim citizens, mobilised by cow protection 
campaigns and other cultural issues (Ding and Slater 2021). In September 2019 the government imposed a lockdown in Kashmir and revoked the constitutional right of Kashmir to political autonomy. In so doing the government further evoked Kashmiri Muslims as a kind of representative other: Mrido Rai argues that 'Kashmiri Muslims are made to serve as contrapuntal symbols — of terrorist violence, illegitimate religious impulses, sedition—-for contriving a mythical Hindu nation' (Rai 2019: 259).

Schmitt's search for the enemy always has this counterpoint: the construction of the united, homogeneous nation, a community defined by lines of difference. The image of this whole nation often refers back to an imagined, lost past. Anustup Basu argues that Hindu nationalism seeks a period of lost unity - an 'idealisation of the nation as a singular Samaj (society)', which 'takes the shape of an organismic Varna harmony rather than a contractual social order' (Basu 2020: 48). Hindu nationalists conjure up an idea of a 'spectral country in-essence', an imagined pure nation, which must 'be "taken back" from time to time, in extreme cases, from minorities, the bureaucratic government, or the legal and constitutional order itself' (Basu 2020: 13-14).

In the Sri Lankan context, David Rampton points to the ever-present frontier articulated in Sinhala nationalist discourse between the imagined nation and its external enemies. While the identity of enemies may change, the frontier 'remains a key element in fuelling a nationalist desire for [...] the reinvigoration of the lost glory of Buddhist kingdoms; of the ancient past through the reunification of the island as a Sinhala Buddhist state and society' (Rampton 2012: 379). There is little room for minorities to define their own identity within this antipluralist vision of unity. In a speech by President Rajapaksa in 2009, he claimed that 'We have removed the word minorities from our vocabulary. ... No longer are there Tamils, Muslims, Burghers, Malays and any other minorities'. Instead, claimed Rajapaksa, there were only two groups in the country: one was the 'people that love this country'; the other comprised people 'that have no love for the land of their birth' (Rajapaksa 2009). In articulating such a dividing line, political leaders seek to construct a new, united political community. But what emerges is not a new, inclusive unity, but a majoritarian polity, informed by the politics and culture of the majority group and too often characterised by violence against minorities. In the Sri Lankan case, after the war against the LTTE came to an end, there was an increase in violent attacks on the minority Muslim community (Mihlar 2019).

\section{Democracy}

Ding and Slater make the important point that indicators of autocratization do not all trend in the same direction. They point to a 'gap that has emerged between two core features of democracy: elections and rights' (Ding and Slater 2021: 65). Varieties of Democracy data demonstrates that 'electoral quality widely advanced on a global scale over the decade from 2007 to 2017, while rights and freedoms for individual citizens generally receded' (Ding and Slater 2021: 68). They identify cases in South Asia - notably India and Sri Lanka - as representative of this global trend. Ding and Slater use an institutionalist approach to interpret the divergent paths of electoral and rights institutions in a pattern which they term 'democratic decoupling', where 'a decline in rights may coexist with elections of consistent or even improving quality' (Ding and Slater 2021: 67). But much can also be learnt by applying Schmitt's theoretical approach to understand the potential tension between liberal rights and democratic elections.

Schmitt argued that the combination of liberalism with democracy was a fatal oxymoron: not merely a 'structural tension' as Ding and Slater phrase it, but an unsustainable 
contradiction that always threatens to undermine the political order. Schmitt, versed in the shortcomings of the Weimar republic, was highly critical of parliamentary democracy, of any attempts to mediate the popular will through representative institutions and constitutional norms. Schmitt complains that 'modern mass democracy rests on the confused combination of both [liberalism and democracy]' (Schmitt 1985b: 13). His aim is to split apart 'democracy' and 'parliamentarism', and to recover a version of democracy in which the popular will is no longer constrained by liberal norms, the rule of law and mediating institutions, but is united in its acclamation of support for a sovereign leader. In short, he argues that 'democracy can exist without what one today calls parliamentarism and parliamentarism without democracy; and dictatorship is just as little the definitive antithesis of democracy as democracy is of dictatorship' (Schmitt 1985b: 32).

This attempt to pull apart liberalism and democracy is at the heart of the majoritarian politics of autocratization in South Asia, in which elections have often enabled rather than constrained democratic regression. Despite the pressure on liberal norms and civil rights, the BJP further increased its parliamentary majority at the May 2019 election and Prime Minister Modi enjoyed high approval ratings of $74 \%$ in January 2021 - only $8 \%$ of those polled considered that he had done a bad job as prime minister (India Today 2021). In Sri Lanka, Gotabaya Rajapaksa enjoyed an easy victory at the polls in November 2019, winning 52\% of the votes cast to his opponent's 41\%, and garnering big majorities in the Sinhala heartland. In Bangladesh the opposition boycott of the 2014 election led to complete domination of the parliament by the Awami League (AL). In Pakistan Imran Khan's victory at the polls in July 2018 also represented a populist shift in the Pakistan establishment's search for support among a new, aspirant middle class (Akhtar 2021). Majoritarian democracy now represents the default political logic across South Asia.

Hansen explores how the political idea of representing majorities, as opposed to political parties that gained votes across different constituencies, became increasingly dominant in India after the 1990s. This was not merely electoral calculation, but something deeper, in which 'The notion of majority itself - bahumat - began to acquire a stronger affective and moral force' (Hansen 2019: 30). The emergence of majoritarianism in India has specific roots in postcolonial, linguistic and regional politics, but it also reflected a global trend, in which populist and authoritarian leaders frequently invoked the idea of a natural conservative majority stifled by the minority views of liberal elites (Lewis 2020a: 93-99). Liberalism, argued conservative thinkers, is not designed to represent the majority but to contain it. Schmitt's authoritarianism, by contrast, claims to liberate the voice of the majority in support of the sovereign leader and in denunciation of their enemies. Similar thinking is often evident in Sri Lanka, where Sinhala nationalists prioritised the democratic process as part of a wider legitimation strategy for a majoritarian politics and viewed democracy as a mechanism by which the voice of the Sinhala majority - too often stifled historically by minority groups or foreign powers - could finally be heard (Lewis 2020b).

While Schmittian authoritarianism claims to offer a way for the popular will to be articulated, Schmitt is also candid about how that popular will might be shaped and manipulated. On the one hand, Schmitt expects the state to reflect and channel some kind of submerged popular understanding about a people's place in the world. But at the same time, Schmitt is also clear that everything depends on "who has control over the means with which the will of the people is to be constructed: military and political force, propaganda, control of public opinion through the press, party organisations, assemblies, popular education, and schools' (Schmitt 1985b: 29). Schmitt's thinking is summarised by the contradictory thought that 'only political power, which should come from the people's will, can form the people's 
will in the first place' (Schmitt 1985b: 29). Hansen echoes this thinking in his argument that 'the mightiest socio-political force in India today is neither the state nor the law but deeply embedded vernacular ideas of popular sovereignty', in which the category of 'the people' is not pre-given but 'needs to be continuously filled and performed in order to remain potent' (Hansen 2019: 35). In other words, governments and their allies must work hard to police discourse and undermine alternative views through new forms of censorship and control over freedom of speech. Autocratization in South Asian politics is most evident in the growing crackdown on dissent across the region, even in countries such as India, where freedom of speech and plurality of opinion have a long tradition. At the same time, governments work hard to develop and maintain a 'hegemonic discourse' - circulating ideas, tropes and narratives in society to promote the ruling elite's values and norms and to legitimise their hold on power (Lewis 2016).

\section{Conclusion}

Autocratization in South Asia is not divorced from global trends. Its specific contextual framework does little to disguise an underlying set of principles that reflects a wider, global backlash against liberalism. The democratic recession in the region is not simply the consequence of domestic institutional weaknesses or the decline of Western power, but reflects a global ideological challenge to the dominant norms and ideas of post-Cold War liberalism. The work of the anti-liberal thinker Carl Schmitt helps to interpret these trends and locate them in a coherent, ideological framework. Schmitt's authoritarian state is an abstracted, ideal type, and the reality of present-day autocratization is a messy reflection of his vision. South Asian states contain pluralistic societies which continue to contest many aspects of the current wave of autocratization. Yet states in the region are also experiencing profound challenges to liberal democracy that Schmitt would have recognised: the affective allure of majoritarian politics; the simplicity of a world divided into friends and enemies; the appeal of the leader who can cut through bureaucracy and special interests to make a decision. These are all powerful ideas that have remarkable emotional reach in a complex and threatening world. They reflect new ideological forces that are driving South Asia's autocratization and to which liberals in the region have yet to find a convincing answer.

\section{Bibliography}

Akhtar, Aasim Sajjad (2021) 'The war of terror in praetorian Pakistan: The emergence and struggle of the Pashtun Tahaffuz movement', Journal of Contemporary Asia, 51(3): 516-529.

Basu, Anustup (2020) Hindutva as political monotheism (Duke University Press).

Bermeo, Nancy (2015) 'On democratic backsliding', Journal of Democracy, 27(1), pp. 5-19.

Bettiza, Gregorio, and David Lewis (2020) 'Authoritarian powers and norm contestation in the liberal international order: Theorizing the power politics of ideas and identity', Journal of Global Security Studies, 5(4), pp. 559-577.

Coomaraswamy, R. and C. de Los Reyes (2004) 'Rule by emergency: Sri Lanka's postcolonial constitutional experience', International Journal of Constitutional Law, 2(2), pp. 272-295.

Crisis Group (2013) 'Impeachment of the Sri Lankan ChiefJustice', International Crisis Group, 13 January 2013. Available at: www.crisisgroup.org/asia/south-asia/sri-lanka/impeachment-sri-lankan-chief-justice

Croissant, Aurel and Jeffrey Haynes (2021) 'Democratic regression in Asia: introduction', Democratization, 28(1), pp. 1-21.

DeVotta, Neil (2011) 'Sri Lanka: From turmoil to dynasty', Journal of Democracy, 22(2), pp. 130-144.

Diamond, Larry (2021) 'Democratic regression in comparative perspective: scope, methods, and causes', Democratization, 28(1), pp. 22-24. 
Ding, Iza and Dan Slater (2021) 'Democratic decoupling', Democratization, 28(1), pp. 63-80.

Hansen, Thomas Blom (2019) 'Democracy against the law: reflections on India's illiberal democracy', in A. P. Chatterji, T. B. Hansen, and C. Jaffrelot (eds.) Majoritarian state: How Hindu nationalism is changing India (Oxford: Oxford University Press), pp. 19-40.

HRW (2020) 'India: New reports of extrajudicial killings in Kashmir', Human Rights Watch. 14 August 2020. Available at: www.hrw.org/news/2020/08/14/india-new-reports-extrajudicial-killings-kashmir

HRW (2021) 'World Report 2021 - India', Human Rights Watch. Available at: www.hrw.org/worldreport/2021/country-chapters/india

India Today (2021) 'Mood of the Nation', India Today, January. Available at: www.indiatoday.in/moodof-the-nation-survey-2021 (accessed 6 May 2021).

Kendall-Taylor, Andrea, Erica Frantz, and Joseph Wright (2017) 'The global rise of personalized politics: It's not just dictators anymore', The Washington Quarterly, 40(1), pp. 7-19.

Lewis, David (2016) 'Blogging Zhanaozen: hegemonic discourse and authoritarian resilience in Kazakhstan', Central Asian Survey, 35(3), pp. 421-438.

Lewis, David G. (2020a) Russia's new authoritarianism: Putin and the politics of order (Edinburgh: Edinburgh University Press).

Lewis, David G. (2020b) 'Sri Lanka’s Schmittian peace: sovereignty, enmity and illiberal order', Conflict, Security and Development, 20(1), pp. 15-37.

Libin, Xie, and Haig Patapan (2020) 'Schmitt fever: The use and abuse of Carl Schmitt in contemporary China', International Journal of Constitutional Law, 18(1), pp. 130-146.

McCormick, J. (1998) 'Review: political theory and political theology - the second wave of Carl Schmitt', Political Theory, 26(6), pp. 830-854.

Mehring, R. (2014) Carl Schmitt: A biography (trans. by D. Steuer, Cambridge: Polity).

Mehta, P. B. (2020) 'Betrayal of procedure in Parliament is not just about technicalities. Deference to process builds trust', The Indian Express, 22 September. Available at: https://indianexpress.com/ article/opinion/columns/parliament-monsoon-session-farm-bills-modi-govt-railroading-thebill-6605281/

Mehta, T. (2020) 'Vikas Dubey and the problem of "encounter killings" in India', The Diplomat, 17 July. Available at: https://thediplomat.com/2020/07/vikas-dubey-and-the-problem-of-encounterkillings-in-india/

Meierhenrich, J. and O. Simons (2016) 'A fanatic of order in an epoch of confusing turmoil', in J. Meierhenrich and O. Simons (eds.) The Oxford Handbook of Carl Schmitt (Oxford: Oxford University Press), pp. 3-70.

Mihlar, Farah (2019) 'Religious change in a minority context: transforming Islam in Sri Lanka', Third World Quarterly, 40(12), 2153-2169.

Müller, Jan-Werner (2003) A dangerous mind: Carl Schmitt in post-war European thought (New Haven: Yale University Press).

Rai, Mridu (2019) 'Kashmiris in the Hindu Rashtra', in A. P. Chatterji, T. B. Hansen, and C. Jaffrelot (eds.) Majoritarian state: How Hindu nationalism is changing India (Oxford: Oxford University Press), pp. 259-280.

Rampton, D. (2012) 'A game of mirrors: Constitutionalism and exceptionalism in a context of nationalist hegemony', in A. Welikala (ed.) The Sri Lanka Republic at 40: Reflections on constitutional history, theory, and practice (Centre for Policy Alternatives, Colombo), pp. 364-401.

Rajapaksa, M. (2009) 'President Rajapaksa's Speech to Parliament on the Defeat of the LTTE, 19 May 2009. Available at: http://old.satp.org/satporgtp/countries/shrilanka/document/papers/president_ speech_parliament_defeatofLTTE.htm (accessed 1 May 2021).

Riaz, Ali (2021). 'The pathway of democratic backsliding in Bangladesh', Democratization, 28(1), pp. $179-197$.

Schmitt, C. (1985a [1934]) Political theology: Four chapters on the concept of sovereignty (trans. by G. Schwab, Cambridge, MA: MIT Press).

Schmitt, C. (1985b [1926]) The crisis of parliamentary democracy (trans. by E. Kennedy, Cambridge, MA: MIT Press).

Schmitt, C. (1991) Glossarium: Aufzeichnungen der Jahre 1947-1951 (ed. by Eberhard Freiherr von Medem) (Berlin: Duncker and Humblot).

Schmitt, C. (2004 [1932]) Legality and legitimacy (Durham, NC: Duke University Press).

Schmitt, C. (2007) Concept of the political (Chicago: University of Chicago Press). 
Shah, A. P. (2020) 'The only institution capable of stopping the death of democracy is aiding it', The Wire, 18 September. Available at: https://thewire.in/law/supreme-court-rights-uapa-bjp-nda-masterof-roster (accessed 6 May 2021).

Zheng, Q. (2015) Carl Schmitt, Mao Zedong and the politics of transition (Basingstoke: Palgrave Macmillan). 